\title{
A rare observation of Atlantic halibut larvae (Hippoglossus hippoglossus) in Skjerstadfjorden, North Norway
}

\author{
TERJE VAN DER MEEREN ${ }^{1}$, GEIR DAHLE ${ }^{2}$ AND OLE I. PAULSEN ${ }^{2}$ \\ ${ }^{1}$ Institute of Marine Research, Austevoll Research Station, NO-5392 Storebø, Norway, ${ }^{2}$ Institute of Marine Research, PO Box 1870 \\ Nordnes, NO-5817, Bergen, Norway
}

\begin{abstract}
Four larvae of Atlantic halibut (Hippoglossus hippoglossus) were collected during a larval survey for Atlantic cod (Gadus morhua) in true inshore and shallow locations in the Norwegian fjord system Skjerstadfjorden. This observation contributes to the previous 57 larval specimens ever found for Atlantic halibut and is in accordance with earlier findings from aquaculture research on an ontogenetic change in phototaxi during larval development in this species. The catch sites indicate that shallow water in fjord systems may be of importance as nursery areas for early life stages of Atlantic halibut along the Norwegian coast.
\end{abstract}

Keywords: Atlantic halibut, Hippoglossus hippoglossus, larval ecology, spawning ground, larval distribution, microsatellite identification, nursery area

Submitted 6 March 2013; accepted 19 May 2013

\section{INTRODUCTION}

Atlantic halibut (Hippoglossus hippoglossus L.) is widely distributed on the shelf and slope areas of the North Atlantic waters and also into the Arctic region, covering areas from New England (USA) and northwards into the Davis Strait, East and West Greenland, Iceland, Faroe Island, Great Britain and Irish waters, south into the Bay of Biscay, the North Sea, western Baltic, Norwegian coast, and the Barents Sea, extending east to Novaja Semlya (Haug, 1990). Atlantic halibut belongs to class Osteichthyes, order Pleuronectiformes, and family Pleuronectidae, commonly also called 'right-eyed flounders'. Only two species exist within the genus Hippoglossus Cuvier 1817, the other one being the closely related Pacific halibut (Hippoglossus stenolepis Schmidt, 1904).

Little is known of the life history of Atlantic halibut (Haug, 1990; Trumble et al., 1993), in particular for the early life stages, and much of the knowledge from these early phases of development has been achieved from the propagation of halibut in aquaculture (Mangor-Jensen et al., 1998). Spawning areas such as oceanic deep-water slopes have mainly been indicated by the occurrence of planktonic eggs and larvae, and the occasional catches of adult fish with running or spent gonads (Haug, 1990). In Norwegian coastal waters it is reported that Atlantic halibut spawns over soft bottom at 300-700 m depth (Devold, 1938), which also are locations found in the deep fjords.

However, records of Atlantic halibut larvae from their natural environment are extremely rare. Of the 57 previously

Corresponding author:

T. van der Meeren

Email: terje.van.der.meeren@imr.no reported catches of halibut larvae, most were found in the mid or western region of the distribution area, whereas only one larva has ever been recorded in Norwegian waters (Haug et al., 1989). The present observation is the first record of Atlantic halibut larvae from true inshore locations, more precisely a deep fjord system with very shallow sills at the entrance.

\section{MATERIALS AND METHDDS}

Four halibut-like larvae were collected during sampling of larval Atlantic cod (Gadus morhua L.) in Skjerstadfjorden, a $50 \mathrm{~km}$ long and $516 \mathrm{~m}$ deep landlocked fjord system that has three narrow entrances, Sundstraumen, Saltstraumen, and Godøystraumen, with depths of 11, 26 and $1 \mathrm{~m}$, respectively (Figure 1). The larvae were recovered from the plankton collected during two $30 \mathrm{~min}$ sub-surface tows (2 knots, $3-5 \mathrm{~m}$ depth) with a $350 \mu \mathrm{m}$ Juday net (80 cm diameter) on $2-3$ May 2011. The first larva was caught in Mjønesosen in Valnesfjorden $\left(67^{\circ} 18^{\prime} \mathrm{N} 15^{\circ} \mathrm{O} 1^{\prime} \mathrm{E}\right)$, and the next three larvae were caught in one tow in the inner part of Fauskevika $\left(67^{\circ} 15.5^{\prime} \mathrm{N} 15^{\circ} 25^{\prime} \mathrm{E}\right)$ (Figure 1$)$. Both hauls were taken in locations of relatively shallow water $(5-80 \mathrm{~m}$ depth) in side branches of the Skjerstadfjorden, which coastal Atlantic cod use as spawning grounds and nursery area for their larvae. Since larval size could not be precisely determined, approximate standard length was therefore estimated from size relationships between copepods (Calanus finmarchicus L.) and one of the larvae photographed by an Olympus $\mu$-mini digital compact camera. The sampled larvae were fixed in absolute ethanol for DNA microsatellite identification. DNA was isolated from the four larvae using the HotSHOT protocol described previously by Truett et al. (2000), and analysed with 


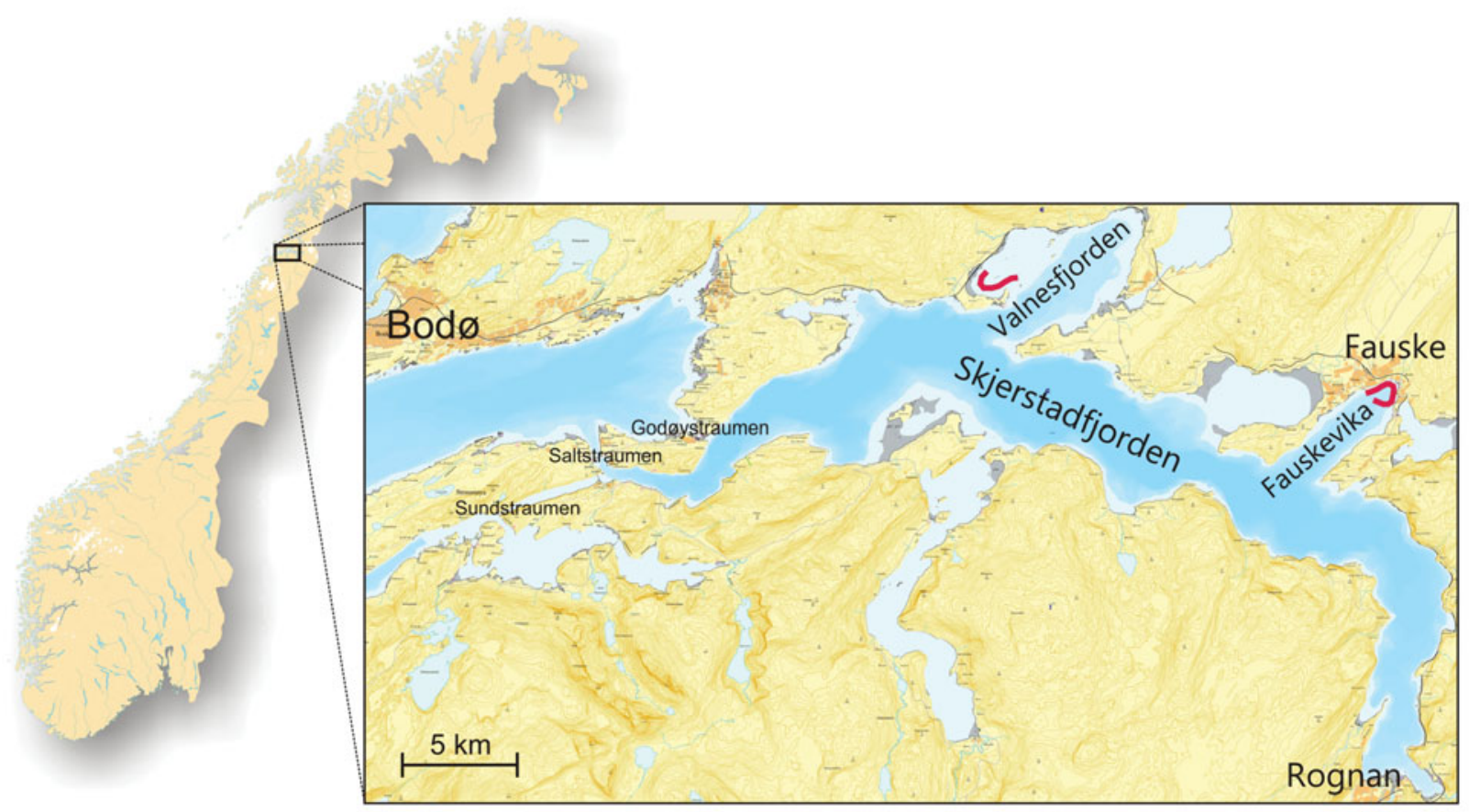

Fig. 1. Location of tows where Atlantic halibut (Hippoglossus hippoglossus) larvae were collected (red or thick black curved line) in Valnesfjorden and Fauskevika.

six species-specific microsatellites Hhi3, Hhi52, Hhi53, Hhi56, Hhi59 and Hhi6o (Coughlan et al., 2000).

\section{RESULTS}

The occurrence of Atlantic halibut larvae coincided with the highest catches of larval Atlantic cod during the entire survey. The microsatellite amplification gave clear fragments for all the four halibut larvae, and assignment analysis using GeneClass2 (Piry et al., 2004) against Atlantic and Pacific halibut as reference samples, assigned all four specimens as Atlantic halibut. In addition, a comparison with a sample of Atlantic halibut individuals previously collected along the Norwegian coast showed no differentiation.

All four halibut larvae were of similar developmental stage, and the standard length of one larva was estimated to $15 \mathrm{~mm}$. All of the halibut larvae had food in their guts and had reached a developmental stage that corresponded to approximately two weeks after the establishment of exogenous feeding (Pittman et al., 1987). The larvae were sparsely pigmented and had melanophores between the myomeres. In addition, dorso- and ventrolateral rows, and dorsal and ventral contour rows of melanophores were observed at the edge of the primordial fin, including a preanal ventral abdominal contour row of tiny melanophores. Two distinct areas of melanophores were observed above the brain (occipital and neck), and two other pigmented areas were seen at the angle of the lower jaw and in the heart region (Figure 2). The caudal tip of the notochord was just barely bent upwards. The observed larvae corresponded to the $13.5 \mathrm{~mm}$ Atlantic halibut larva first drawn by Schmidt (1904), and which was referred to as postlarva. Further, the collected halibut larvae from Skjerstadfjorden also matched stage 3 larvae as given by Thompson \& Van Cleve (1936) for the closely related

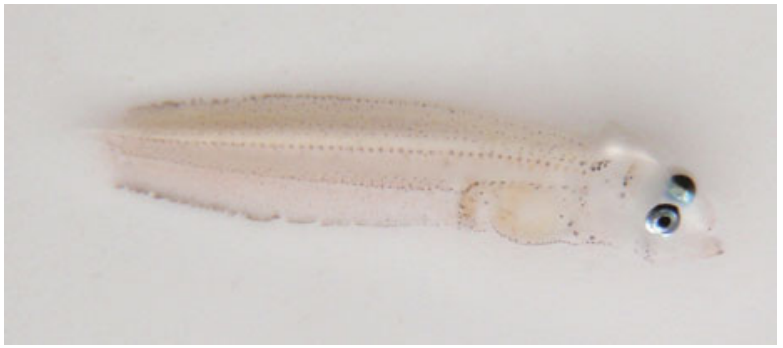

Fig. 2. Hippoglossus hippoglossus larva, $15 \mathrm{~mm}$ standard length, from Fauskevika, Skjerstadfjorden, North Norway.

Pacific halibut species, and are among the younger larval specimens of Atlantic halibut recovered from the sea.

\section{DISCUSSION}

The observations of feeding larvae close to the surface are in accordance with the previous findings of halibut larval behaviour. In a review of halibut biology, Haug (1990) noted that larger (and hence older) larvae were found closest to the surface. This corresponds to an ontogenetic change in larval reaction to light, from displaying negative phototaxi during most yolk-sac stages, to strong phototaxi at the commencement of exogenous feeding (Mangor-Jensen \& Naas, 1993). This change in behaviour is used to concentrate and collect yolk-sac larvae from the silo incubators at transfer to startfeeding units in halibut hatcheries (Harboe et al., 1994). Light controls a profound part of the early life stages of Atlantic halibut. Spawning takes place well below the euphotic zone to keep the eggs in the dark to prevent light from inhibiting hatching (Helvik \& Walther, 1992). Although not yet observed in the sea, yolk-sac larvae are, as interpreted from 
their negative phototaxi, most likely bathypelagic and thus distributed in deep water. Later, the ontogenetic shift in phototaxi will bring the halibut larvae up in the euphotic zone and close to the surface layers where various stages of copepods will be available for exogenous feeding.

Our observations of four young Atlantic halibut larvae in Skjerstadfjorden indicate that this species spawns in such inshore fjord systems. This is in accordance with reports from local fishermen who catch mature halibut in Skjerstadfjorden during the late winter, and who also report catches of juvenile halibut in the nets used in the fishery for coastal Atlantic cod during the spawning season from February to April. Skjerstadfjorden has the right depth and bottom characteristics for containing Atlantic halibut spawning grounds (Devold, 1938). In addition, the hydrographical conditions provide a well mixed water column with good oxygen conditions all year round even at the greatest depths of the fjord basin (Skreslet, 2002). Many of the Norwegian fjords share the spatial, hydrographical, and bottom sediment characteristics of Skjerstadfjorden, and may possibly also have spawning grounds for Atlantic halibut. Devold (1938) reported that females with running roe were caught in Sørfolla, the neighbouring fjord system of Skjerstadfjorden to the north, and that eggs have been collected by tow-netting of long duration in deep water from the Trondheimsfjord, Glåmfjord, and Økssund.

It is also intriguing that all the four halibut larvae were recovered on or in close vicinity of cod spawning grounds in Skjerstadfjorden. Our findings indicate that such shallow areas may be of particular importance for the early life history of Atlantic halibut along the Norwegian coast. Furthermore, the fishermen's reports of juvenile halibut on the cod spawning grounds point to the existence of juvenile nursery areas after larval settling in the same shallow areas of the fjord system. This is in accordance with observations of well defined nursing areas of young Atlantic halibut at 20-60 m depth from the more open coastal regions (Haug, 1990). The fjords have mostly steep walls, and the more shallow parts of the fjords which serve as larval and juvenile nursery areas for a number of marine fish species are scarcer. Thus, such areas may need special attention with respect to anthropogenic influence since they may represent important habitats for the early life stages of coastal fish populations.

Studies on fjord ecology have focused on food web dynamics (Brattegard et al., 2011), and not so much on life history aspects of large fish that comprise all stages from plankton (eggs and larvae) to some of the larger predators in coastal ecosystems. The International Council for Exploration of the Sea has recommended a zero quota in the fishery for Norwegian coastal cod since 2004 (ICES, 2012), and on parts of the Norwegian coast Atlantic halibut is also considered threatened. Our knowledge about Atlantic halibut larvae in the wild is restricted to a handful of collected specimens, and the yolk-sac larvae have never been found (Haug, 1990). Any new observations of larval halibut may help us to have a better understanding of early life history dynamics in this species. It is therefore time to increase our research effort on coastal fish population dynamics and their part in the coastal ecosystems, including stock structure, genetic diversification, and the most important link to their recruitment: the habitat and food web dynamics of the early life stages and their interactions with anthropogenic activity.

\section{ACKNDWLEDGEMENTS}

We thank Petter Kristiansen for providing us with an excellent boat for the larval surveys, and for his skills and help in operating the boat and sampling gear. We also thank Rolf Sigurdsen for his good suggestion on where to find the spawning sites for Atlantic cod in Skjerstadfjorden. Thanks also to Dr Roderick Nigel Finn for useful linguistic comments. The cod sampling programme in Skjerstadfjorden was supported by the Norwegian Ministry of Fishery and Coastal Affairs.

\section{REFERENCES}

Brattegard T., Høisæter T., Sjøtun K., Fenchel T. and Uiblein F. (2011) Norwegian fjords: from natural history to ecosystem ecology and beyond. Marine Biology Research 7, 421-424.

Coughlan J., Stefansson M., Galvin P., Dillane E., Fitzgerald R. and Cross T.F. (2000) Isolation and characterization of 11 microsatellite loci in Atlantic halibut (Hippoglossus hippoglossus L.). Molecular Ecology 9, 817-829.

Devold F. (1938) The North Atlantic halibut and net fishing. Report on Norwegian Fishery and Marine Investigations 5, 5-47.

ICES (2012) Report of the ICES Advisory Committee, 2012. The Barents Sea and the Norwegian Sea. International Council for the Exploration of the Sea (CM Papers and Reports), ICES Advice 2012, Book 3, 1-7.

Harboe T., Tuene S., Mangor-Jensen A., Rabben H. and Huse I. (1994) Design and operation of an incubator for yolk-sac larvae of Atlantic halibut. The Progressive Fish-Culturist 56, 188-193.

Haug T. (1990) Biology of the Atlantic halibut Hippoglossus hippoglossus (L., 1758). Advances in Marine Biology 26, 1-70.

Haug T., Kjørsvik E. and Pittman K. (1989) Observations on a wild Atlantic halibut larva Hippoglossus hippoglossus (L.). Journal of Fish Biology 34, 799-801.

Helvik J.V. and Walther B.T. (1992) Photo-regulation of the hatching process of halibut (Hippoglossus hippoglossus) eggs. Journal of Experimental Zoology 263, 204-209.

Mangor-Jensen A. and Naas K.E. (1993) Phototaxis of Atlantic halibut larvae (Hippoglossus hippoglossus L.). In Walther B.T. and Fyhn H.J. (eds) Physiological and biochemical aspects of fish development. Bergen: University of Bergen, Grafisk Hus, pp. 132-138.

Mangor-Jensen A., Harboe T., Shields R.J., Gara B. and Naas K.E. (1998) Atlantic halibut, Hippoglossus hippoglossus L., larvae cultivation literature, including a bibliography. Aquaculture Research 29, 857 886.

Piry S., Alapetite A., Cornuet J.-M., Paetkau D., Baudouin L. and Estoup A. (2004) GeneClass2: A Software for Genetic Assignment and First-Generation Migrant Detection. Journal of Heredity 95, $536-539$.

Pittman K., Berg L. and Naas K.E. (1987) Morphological development of halibut (Hippoglossus hippoglossus L.) larvae with special reference to mouth development and metamorphosis. International Council for the Exploration of the Sea (CM Papers and Reports), CM 1987/F:18, 22 pp.

Schmidt J. (1904) On the pelagic post-larval halibut Hippoglossus vulgaris Flem. and H. hippoglosoides (Walb). Meddelelser fra Kommissionen for Havundersøgelser: Serie fiskeri 1, 1-13.

Skreslet S. (2002) Miljøundersøkelse i Skjerstadfjorden I. Resultater fra måleprogrammet. Høyskolen i Bodø, HBO-rapport 2/2002. Available at www.saltenaqua.no/index.php? $1=$ miljo (accessed 1 March 2013). [In Norwegian.] 
Thompson W.F. and Van Cleve R. (1936) Life history of the Pacific halibut. Report of the International Fisheries Commission 9, 1-184.

Truett G.E., Heeger P., Mynat R.L., Truett A.A., Walker J.A. and Warman M.L. (2000) Preparation of PCR-quality mouse genomic DNA with hot sodium hydroxide and Tris (HotSHOT). BioTechniques 29, 52-54

and

Trumble R.J., Neilson J.D., Bowering W.R. and McCaughran D.A. (1993) Atlantic halibut (Hippoglossus hippoglossus) and Pacific halibut (H. stenolepis) and their North American fisheries. Canadian Bulletin of Fisheries and Aquatic Sciences 227, 1-84.

\section{Correspondence should be addressed to:}

T. van der Meeren

Institute of Marine Research, Austevoll Research Station NO-5392 Storebø, Norway

email: terje.van.der.meeren@imr.no 